OPEN ACCESS

Edited by:

Janarthanan Jayawickramarajah, Tulane University, United States

Reviewed by:

Sriram Kanvah,

Indian Institute of Technology

Gandhinagar, India

Harekrushna Sahoo,

National Institute of Technology

Rourkela, India

*Correspondence:

Thomas R. Wilks

t.r.wilks@bham.ac.uk

Specialty section:

This article was submitted to

Supramolecular Chemistry,

a section of the journal

Frontiers in Chemistry

Received: 08 November 2019 Accepted: 14 January 2020

Published: 31 January 2020

Citation:

Núñez-Pertíñez S and Wilks TR (2020)

Deep Eutectic Solvents as Media for

the Prebiotic DNA-Templated

Synthesis of Peptides.

Front. Chem. 8:41

doi: $10.3389 /$ fchem.2020.00041

\section{Deep Eutectic Solvents as Media for the Prebiotic DNA-Templated Synthesis of Peptides}

\author{
Samuel Núñez-Pertíñez and Thomas R. Wilks* \\ School of Chemistry, University of Birmingham, Birmingham, United Kingdom
}

Translation of genetic information into peptide products is one of the fundamental processes of biology. How this occurred prebiotically, in the absence of enzyme catalysts, is an intriguing question. Nucleic acid-templated synthesis (NATS) promotes reactions by bringing building blocks tethered to complementary DNA strands into close proximity and has been shown to enable peptide synthesis without enzymes - it could therefore serve as a model for prebiotic translation of information stored in nucleic acid sequences into functional peptides. The decomposition of highly reactive DNA adapters has so far limited the effectiveness of NATS, but these studies have been performed exclusively in aqueous solution. Deep eutectic solvents (DESs) have been proposed as a feasible solvent for prebiotic replication of nucleic acids, and here are studied as media for prebiotic translation using NATS as a model. DESs are shown to enhance the stability of DNA-conjugated activated esters, the precursors of peptides. However, this enhanced stability was coupled with decreased amine reactivity that hampered the formation of peptide bonds in DESs. These properties are exploited to demonstrate the storage of DNA-conjugated activated esters in a DES followed by transfer into aqueous buffer to activate the NATS of peptides "on demand." These findings, together with the reported functions of DESs in prebiotic processes, shed light on how DESs could have facilitated the non-enzymatic translation of genetic information into functional peptides on the early Earth.

Keywords: prebiotic, translation, deep eutectic solvent, templated synthesis, nucleic acids

\section{INTRODUCTION}

Living organisms preserve the information required to synthesize their molecular components in nucleic acid sequences (Crick, 1970). The replication of this genetic material, and its translation into active catalytic proteins is regulated and catalyzed by highly complex molecular machines. Perhaps the most impressive example is the biosynthesis of peptides and proteins by the ribosome (Steitz, 2008; Yonath, 2009). A key question is how these processes were performed prebiotically, in the absence of such complex machinery. Based on the fact that the core of the ribosome is made from RNA, it has been proposed that replication and translation were first performed by simple nucleic acids, giving rise to the "RNA world" (Crick, 1968; Orgel, 1968; Kruger et al., 1982; Guerrier-Takada et al., 1983; Gilbert, 1986) and "RNA/peptide world" hypotheses (Yarus, 2001; Turk et al., 2010). Several nucleic acid systems that display enzyme-free self-replication have been described (Ekland and Bartel, 1996; Johnston et al., 2001; Paul and Joyce, 2002; Li et al., 2017; Hänle and Richert, 2018; Liu et al., 2018; Mariani et al., 2018; Zhang et al., 2019), and there have been a handful of 
mechanisms proposed for prebiotic translation (Zhang and Cech, 1997; Tamura and Schimmel, 2001, 2004). However, these studies have highlighted a number of obstacles to achieving efficient replication and translation in the absence of enzymes: (1) the hydrolysis of the highly reactive, activated monomers required for both processes is rapid in aqueous solution (Kanavarioti et al., 1989); (2) hydrolysed monomers can inhibit replication and induce errors in translation (Deck et al., 2011); (3) after replication, long strands will hybridize to form stable duplexes, blocking further replication by template inhibition (Szostak, 2012).

Most studies in this area have assumed that the solvent for these prebiotic processes was aqueous, but deep eutectic solvents (DESs) have recently emerged as an alternative (He et al., 2017). DESs are a family of solvents, closely related to ionic liquids, composed of a hydrogen bond donor and a salt that form a eutectic mixture at a specific molar ratio (Abbott et al., 2003). Most DESs have high viscosity, low vapor pressure and a very high concentration of ionic species (Zhang et al., 2012; Smith et al., 2014), and their basic components, such as glycerol or urea, are likely to have been present on the early Earth (Kaiser et al., 2015; Okamura et al., 2019). DESs composed of quaternary ammonium salts and hydrogen bond donors (e.g., reline, a mixture of urea and choline chloride) have been shown to be compatible with protein and nucleic acid biomolecules (Wagle et al., 2014; Xu et al., 2017; Pätzold et al., 2019). For example, it was demonstrated that DNA was stable and retained its structural integrity for at least 6 months when stored in a DES (Mondal et al., 2013), that tertiary structures such as A- and B-DNA duplexes, and G-quadruplexes, were maintained (Mamajanov et al., 2010; Lannan et al., 2012; Zhao et al., 2013; Gállego et al., 2015), and that enzymatic peptide synthesis could be performed efficiently (Maugeri et al., 2013). DESs have also been shown to be favorable media for nucleic acid replication. For example, DESs promote the formation of activated organophosphates from mineral phosphate, which is a necessary step in the formation of the activated monomers required for replication (Gull et al., 2014, 2017; Burcar et al., 2016). The high viscosities of DESs also enable more efficient non-enzymatic replication: the faster diffusion of monomers compared to long oligonucleotides in these solvents has been shown to help overcome the template inhibition problem ( $\mathrm{He}$ et al., 2017). High viscosity also favors intramolecular folding over intermolecular interactions, enabling, for example, the recovery of ribozyme activity following a replication process (He et al., 2019).

Based on this previous work around replication, we asked whether DESs could also be suitable media for nonenzymatic translation and chose nucleic acid-templated synthesis (NATS) of a dipeptide as a simple model for this process. NATS promotes reactions by using hybridization to bring reactants tethered to complementary oligonucleotides into close proximity, and has been extensively used in the literature for the programmed production of oligopeptides (Li and Liu, 2004; O'Reilly et al., 2017). Importantly, this previous work has been limited by hydrolysis of the activated building blocks required (Meng et al., 2016). Here, we investigate the NATS of peptides in an archetypal DES, glycholine (a mixture of glycerol and choline chloride). We find that glycholine protects DNA-conjugated activated esters, the necessary precursors of oligopeptide products, from solvolysis. By comparing the NATS of peptides in DESs and aqueous buffered solution we also uncover the inhibitory effect of glycholine on amide bond formation. We exploit these properties to demonstrate the extended storage of otherwise unstable peptide building blocks in glycholine, followed by shuttling into aqueous solution to activate NATS "on demand." Combined with recent theories about the role of compartmentalisation in prebiotic self-replicating systems (Mann, 2012), these experiments hint at a possible role for DESs in enabling non-enzymatic construction of oligopeptides on the early Earth.

\section{MATERIALS AND METHODS}

Nuclear magnetic resonance (NMR): One-dimensional ${ }^{1} \mathrm{H}$ and ${ }^{13} \mathrm{C}$ NMR, and two-dimensional NMR spectra were recorded on a Bruker Advance $300 \mathrm{MHz}$, Bruker Advance III $400 \mathrm{MHz}$ or a Bruker Advance III $500 \mathrm{MHz}$ instrument at $25^{\circ} \mathrm{C}$. Deuterated solvents chloroform- $d$ (99.8 D atom\%), methanol- $d_{4}(99.8 \mathrm{D}$ atom\%), dimethyl sulfoxide- $d_{6}$ (DMSO- $d_{6}, 99.8 \mathrm{D}$ atom\%) acetone- $d_{6}(99.9 \mathrm{D}$ atom\%) were purchased from Sigma Aldrich. The residual non-deuterated solvent peak was used as a chemical shift $(\delta, \mathrm{ppm})$ internal standard. The data were processed using Mestrenova (Mestrelab research) v.12.0.2 and ADC/NMR software. High resolution mass spectrometry (HRMS): HRMS was performed on a Bruker Q-ToF Maxis Plus spectrometer or on a Waters Xevo GS2-XS qToF system. A relative error under 5 ppm was ensured. Reversed-phase high performance liquid chromatography (RP-HPLC): RP-HPLC was performed in a Varian 920LC system with a photodiode array UV detector (PDA), and a fluorescence detector. Liquid chromatography-Mass spectrometry (LC-MS): LC-MS was performed on an Agilent 1200 HPLC system coupled to a Bruker AmazonX high resolution ion trap, in negative ion mode. The desalted oligonucleotide samples were eluted though a XBridge oligonucleotide $\mathrm{BEH} \mathrm{C18}$ column (130 ̊, $2.5 \mu \mathrm{m}, 4.6 \times 50 \mathrm{~mm})$ using a $5 \mathrm{vol} \% \mathrm{MeOH}$, $10 \mathrm{mM}$ ammonium acetate (buffer A) and a $70 \mathrm{vol} \% \mathrm{MeOH}$, $10 \mathrm{mM}$ ammonium acetate (buffer B) solvent system. The data were processed using Compass Data Analysis (Bruker) v.4.1 software, and the MaxEnt integrated deconvolution algorithm. Alternatively, LC-MS was performed on a Waters ACQUITY UPLC system coupled to a Xevo GS2-XS qToF mass spectrometer in negative sensitivity mode with leucine-enkephalin $[\mathrm{M}-\mathrm{H}]^{-}$ 554.2620 Lockspray. The oligonucleotides were eluted through an AQUITY UPLC oligonucleotide BEH C18 column (130 ̊, $1.7 \mu \mathrm{m}, 2.1 \times 50 \mathrm{~mm}$ ) using a $50 \mathrm{mM}$ triethylammonium acetate (TEAA, pH 7.0) solution in $\mathrm{H}_{2} \mathrm{O}$ (buffer A) and a $50 \mathrm{mM}$ TEAA solution in $\mathrm{MeCN}$ (buffer $\mathrm{B}$ ) at $60^{\circ} \mathrm{C}$ and a $0.2 \mathrm{~mL} \cdot \mathrm{min}^{-1}$ flow. Fluorescence spectroscopy: Fluorescence spectral data were recorded on an Agilent Cary Eclipse fluorescence spectrophotometer equipped with a photomultiplier tube (PMT) detector. Quartz cuvettes from Starna scientific (Type 3/Q/10) with four polished sides were used for fluorescence. The emission 
and excitation spectra were recorded using Cary Eclipse v.1.2.0.0 software. Karl Fischer titration: The water content in DESs was determined using an automated CA-200 (Mitsubishi chemicals) Karl Fischer coulometric titrator. Aqualine (Fisher) auxiliary reagent mixture and Aquamicron solution $\mathrm{P}$ (Aquamicron, 3.8-4.0 $\mathrm{mg} \mathrm{H}_{2} \mathrm{O} \cdot \mathrm{mL}^{-1}$ ) calibration standards were used. $p H$ measurements: An Accumet AP110 pH meter kit (Fisher) equipped with a $\mathrm{pH}$ sensitive glass electrode was used to determine the $\mathrm{pH}$ in aqueous solution. Prior to sample analysis, the instrument was calibrated with $\mathrm{pH} 4, \mathrm{pH} 7$, and $\mathrm{pH} 10$ standard solution buffers.

\section{DNA Sequences and Modifications}

Sequences were optimized, and the expected assemblies predicted with NUPACK (Zadeh et al., 2009). Modified DNA strands were purchased from Integrated DNA Technologies and further modified as described below. Sequence data and modification structures are given in Table S1 and Scheme S1.

\section{Synthesis of DESs}

DESs were prepared by mixing appropriate amounts of hydrogen bond donor and choline chloride in a Schlenk round bottom flask under positive nitrogen pressure, heating to $100^{\circ} \mathrm{C}$ and stirring until a homogeneous mixture was obtained. DESs were dried at $80^{\circ} \mathrm{C}$ under vacuum prior to use (Abbott et al., 2004). The $\mathrm{H}_{2} \mathrm{O}$ content of glycholine was determined by Karl Fischer titration. $\mathrm{H}_{2} \mathrm{O}$ content was then adjusted to the desired value. For simplicity, we refer to the volume percentage content of $\mathrm{H}_{2} \mathrm{O}$ in the DES using a subscript number e.g., glycholine containing 7 vol\% $\mathrm{H}_{2} \mathrm{O}$ is written as $\mathrm{Gly}_{0.07}$.

\section{Measurement of DES Solution pH}

DES $(1 \mathrm{~mL})$ was diluted in $\mathrm{H}_{2} \mathrm{O}(4 \mathrm{~mL})$ and the $\mathrm{pH}$ was determined using a $\mathrm{pH}$-sensitive glass electrode. The error was evaluated in two different series of samples, by performing triplicate measurements and determining the standard deviation.

\section{${ }^{1} \mathrm{H}-\mathrm{NMR}$ Spectroscopy Study of The Stability of Small Molecule Activated \\ Esters}

Solutions of $\mathbf{1}$ ( $5 \mathrm{mM})$ in different solvent mixtures were stirred at $24{ }^{\circ} \mathrm{C}$. After 2, 4, 6 and $24 \mathrm{~h}$ the solutions were extracted with $0.7 \mathrm{~mL}$ of either acetone- $d_{6}$ (DES solutions) or chloroform$d$ (phosphate buffer solutions). The relative proportions of $\mathbf{1}$ and 3 were determined by ${ }^{1} \mathrm{H}-\mathrm{NMR}$ spectroscopy (Figure S1).

\section{RP-HPLC Stability Study of Activated Esters}

Activated ester 1 (4.1 mg) was dissolved in DES (2 mL). Each solution was prepared $40 \mathrm{~min}$ after the previous one. The solutions were stirred over a period of $29 \mathrm{~h}$. After stirring for 5,24 , and $29 \mathrm{~h}$, a $100 \mu \mathrm{L}$ aliquot of each sample was diluted in $\mathrm{H}_{2} \mathrm{O}(900 \mu \mathrm{L})$ and the sample analyzed by RPHPLC. Method: column Discovery C18 (Sigma Aldrich, $5 \mu \mathrm{m}$, $10 \times 4.6 \mathrm{~cm}$ ), flow $1 \mathrm{~mL} \cdot \mathrm{min}^{-1}$, temperature $40^{\circ} \mathrm{C}$ and injection volume $10 \mu \mathrm{L}$. Solvent A: $\mathrm{H}_{2} \mathrm{O}, 0.05$ vol\% TFA. Solvent B: 70 vol\% $\mathrm{MeCN}, 0.05$ vol\% TFA.

\section{Thermal Stability of dsDNA in DESs}

The thermal stability of dsDNA in DES solutions was determined using fluorophore and quencher labeled DNA strands (S15 and S16). Solutions of $100 \mathrm{nM}$ dsDNA were briefly centrifuged and placed in a qPCR instrument. Samples were heated and cooled at $1^{\circ} \mathrm{C} \cdot \mathrm{min}^{-1}$. The melting temperature $\left(T_{\mathrm{m}}\right)$ was determined as the middle-point of the sigmoidal trace defined by the fluorescence emission intensity as a function of temperature.

\section{Synthesis of NHS-Activated Fluorescein, S18 (Gao et al., 2002)}

Fluorescein free carboxylic acid $(\mathbf{S 1 7}, 3.322 \mathrm{~g}, 10 \mathrm{mmol})$ and $N$-hydroxysuccinimide $(1.151 \mathrm{~g}, 10 \mathrm{mmol})$ were dissolved in dry DMF $(19 \mathrm{~mL})$ under positive nitrogen pressure in a dry Schlenk tube (Scheme 1). Then, $N, N^{\prime}$-dicyclohexylcarbodiimide (DCC, $2.063 \mathrm{~g}, 10 \mathrm{mmol}$ ) was added and the resulting solution stirred at $60^{\circ} \mathrm{C}$ for $2 \mathrm{~h}$ under positive nitrogen pressure. $N, N^{\prime}$ dicyclohexylurea (DCU) was removed by cooling down the reaction mixture to $-20^{\circ} \mathrm{C}$ for $2 \mathrm{~h}$ and the white precipitate was filtered off. The solvent was removed under reduced pressure and the crude solid was purified by $\mathrm{SiO}_{2}$ column chromatography using an EtOAc/acetone gradient. The desired fractions were combined to produce S18 as a bright orange solid (2.002 g, 47\%). The ${ }^{1} \mathrm{H}$-NMR spectroscopic analysis was in good agreement with the reported characterization (Gao et al., 2002). TLC (EtOAc:MeOH 6:4) $\mathrm{R}_{\mathrm{f}}=0.1 .{ }^{\mathbf{1}} \mathrm{H}-\mathrm{NMR}\left(300 \mathrm{MHz}, \mathrm{DMSO}-d_{6}\right)$ $\delta(\mathrm{ppm}): 8.36(1 \mathrm{H}, \mathrm{d} J=7.7 \mathrm{~Hz}, \mathrm{Ar}-H), 7.96(2 \mathrm{H}, \mathrm{m}, \mathrm{Ar}-H), 7.65$ $(1 \mathrm{H}, \mathrm{d} J=7.5 \mathrm{~Hz}, \mathrm{Ar}-H), 6.79(2 \mathrm{H}, \mathrm{d} J=9.6 \mathrm{~Hz}, \mathrm{Ar}-H), 6.53(4 \mathrm{H}$,<smiles>O=C(O)c1ccccc1-c1c2ccc(=O)cc-2oc2cc(O)ccc12</smiles>

S17

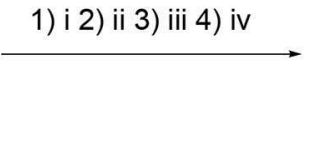

SCHEME 1 | Synthesis of the N-hydroxymaleimide ester S21. (i) SuOH, DCC, DMF, 60 C, 2 h; (ii) TsOH.H-Ala-OBn, Et 3 N, DCM, r.t. 3 h; (iii) Pd/C (10 wt\%), $\mathrm{H}_{2}$, $\mathrm{MeOH}$, r.t., 1.5 h; (iv) N-hydroxymaleimide, DCC, EtOAc:1,4-dioxane (2:1), r.t., o.n. 
m, $\mathrm{Ar}-\mathrm{H}), 2.73\left(4 \mathrm{H}, \mathrm{s}^{\mathrm{br}},\left(\mathrm{CH}_{2}\right)_{2}\right.$ succinimide). HRMS (ESI-) $\mathrm{m} / \mathrm{z}$ $[\mathrm{M}-\mathrm{H}]^{-}$calcd. 428.0770 found 428.0763 .

\section{Synthesis of S19}

S18 $(1.000 \mathrm{~g}, 2.23 \mathrm{mmol})$ and TsOH.H-L-Ala-OBn $(1.637 \mathrm{~g})$ were dissolved in dry DMF $(15 \mathrm{~mL})$ under positive nitrogen pressure in a dry round bottom Schlenk flask. Then, $\mathrm{Et}_{3} \mathrm{~N}(1.1 \mathrm{~mL}$, $8.16 \mathrm{mmol}$ ) was added drop wise over $10 \mathrm{~min}$ and the resulting solution was stirred at room temperature for $6 \mathrm{~h}$. The solvent was removed under reduced pressure and the crude product was purified by $\mathrm{SiO}_{2}$ column chromatography using a $\mathrm{DCM} / \mathrm{MeOH}$ (100:0 to 75:15) gradient to produce $\mathbf{S 1 9}$ as a bright orange solid (704 mg, 61\%). TLC (EtOAc:MeOH 6:4) $\mathrm{R}_{\mathrm{f}}=0.6 .{ }^{1} \mathrm{H}-\mathrm{NMR}$ $\left(400 \mathrm{MHz}\right.$, methanol- $\left.d_{4}\right) \delta(\mathrm{ppm}): 7.76(1 \mathrm{H}, \mathrm{m}, \mathrm{Ar}-H), 7.55(1 \mathrm{H}$, m, Ar- $H), 7.41(1 \mathrm{H}, \mathrm{m}, \operatorname{Ar}-H), 7.21(2 \mathrm{H}, \mathrm{m}, \operatorname{Ar}-H), 7.11(4 \mathrm{H}, \mathrm{m}$, $\mathrm{Ar}-H), 6.88(1 \mathrm{H}, \mathrm{m}, \mathrm{Ar}-H), 6.56(1 \mathrm{H}, \mathrm{m}, \mathrm{Ar}-\mathrm{H}), 6.51(1 \mathrm{H}, \mathrm{m}, \mathrm{Ar}-$ $H), 6.45(1 \mathrm{H}, \mathrm{m}, \mathrm{Ar}-H), 6.20(1 \mathrm{H}, \mathrm{d} J=8.7 \mathrm{~Hz}, \mathrm{Ar}-H), 5.97(1 \mathrm{H}$, $\left.\mathrm{dd} J_{1}=8.7 \mathrm{~Hz} J_{2}=2.5 \mathrm{~Hz}, \mathrm{Ar}-\mathrm{H}\right), 4.80\left(2 \mathrm{H}, \mathrm{m}, \mathrm{OCH}_{2}\right), 3.59(1 \mathrm{H}$, $\left.\mathrm{q} J=7.2 \mathrm{CH}-\mathrm{CH}_{3}\right), 1.02\left(3 \mathrm{H}, \mathrm{d} J=7.2 \mathrm{~Hz}, \mathrm{CH}-\mathrm{CH}_{3}\right) .{ }^{13} \mathrm{C}-\mathrm{NMR}$ $\left(100 \mathrm{MHz}\right.$, methanol- $\left.d_{4}\right) \delta(\mathrm{ppm}): 171.75(C=\mathrm{O}), 168.79(C=\mathrm{O})$, $160.29(\mathrm{C}=\mathrm{O}), 160.13(\mathrm{ArC}), 154.54(\mathrm{ArC}), 154.36(\mathrm{ArC}), 154.24$ (ArC), 136.95 (ArC), $134.40(\mathrm{ArC}-\mathrm{H}), 132.13(\mathrm{ArC}-\mathrm{H}), 130.71$ ( $\mathrm{ArC}-\mathrm{H}), 130.60(\mathrm{ArC}-\mathrm{H}), 129.89(\mathrm{ArC}-\mathrm{H}), 129.53(\mathrm{ArC}), 129.37$ $(\mathrm{ArC}-\mathrm{H}), 129.35(\mathrm{ArC}-\mathrm{H}), 129.15(\mathrm{ArC}), 129.09(\mathrm{ArC}), 125.13$ $(\mathrm{ArC}-\mathrm{H}), 123.55(\mathrm{ArC}-\mathrm{H}), 113.26(\mathrm{ArC}-\mathrm{H}), 112.95(\mathrm{ArC}-\mathrm{H})$, 110.26 ( $\mathrm{ArC}), 109.24(\mathrm{ArC}), 103.59(\mathrm{ArC}-\mathrm{H}), 103.08(\mathrm{ArC}-\mathrm{H})$, $\left.68.08\left(\mathrm{OCH}_{2}\right), 51.55(\mathrm{NCH}), 15.44 \mathrm{CH}_{3}\right)$. HRMS (ESI-) $\mathrm{m} / z$ $[\mathrm{M}-\mathrm{H}]^{-}$calcd. 492.1447 found 492.1457.

\section{Synthesis of $\mathbf{S 2 0}$}

$\mathrm{Pd} /$ charcoal $(50 \mathrm{mg}, 10 \mathrm{wt} \%$ ) was placed in a dry round bottom Schlenk flask under positive nitrogen pressure. S19 $(500 \mathrm{mg}$, $1.01 \mathrm{mmol}$ ) was added and dissolved in degassed $\mathrm{MeOH}$ $(50 \mathrm{~mL})$. The nitrogen atmosphere was replaced with hydrogen by bubbling the solution for $3 \mathrm{~min}$ with a hydrogen balloon. The positive hydrogen pressure was maintained for $1.5 \mathrm{~h}$ with constant stirring at room temperature. The solid-supported catalyst was removed by filtration through celite. The solvent was removed under reduced pressure to produce $\mathbf{S 2 0}$ as a bright yellow solid (375 mg, 92\%). TLC (DCM:MeOH 9:1) $\mathrm{R}_{\mathrm{f}}=0.2 .{ }^{1}{ }^{\mathrm{H}}$ NMR $\left(500 \mathrm{MHz}\right.$, methanol- $\left.d_{4}\right) \delta(\mathrm{ppm}): 7.05(1 \mathrm{H}, \mathrm{m}, \mathrm{Ar}-H), 6.61$ $(3 \mathrm{H}, \mathrm{m}, \mathrm{Ar}-H), 6.48(2 \mathrm{H}, \mathrm{m}, \mathrm{Ar}-H), 6.41\left(1 \mathrm{H}, \mathrm{dd} J_{1}=8.7 \mathrm{~Hz} J_{2}\right.$ $=2.4 \mathrm{~Hz}, \mathrm{Ar}-H), 3.67\left(1 \mathrm{H}, \mathrm{q} J=7.2 \mathrm{~Hz}, \mathrm{CHCH}_{3}\right), 1.20(3 \mathrm{H}, \mathrm{d} J$ $\left.=7.2 \mathrm{~Hz} \mathrm{CHCH}{ }_{3}\right) \cdot{ }^{13} \mathrm{C}-\mathrm{NMR}\left(160 \mathrm{MHz}\right.$, methanol- $\left.d_{4}\right) \delta(\mathrm{ppm})$ : $173.6(C=\mathrm{O}), 169.1(C=\mathrm{O}), 160.6(C=\mathrm{O}), 160.4(\mathrm{ArC}), 154.9$ $(\operatorname{ArC}), 154.6(\operatorname{ArC}), 154.4(\operatorname{ArC}), 134.5(\operatorname{ArC}), 132.5(\operatorname{ArC}), 132.4$ (ArC-H), 130.9 (ArC-H), 130.0 (ArC-H), 113.4 (ArC-H), 113.0 (ArC-H), $110.6(\operatorname{ArC}), 109.6(\operatorname{ArC}), 103.7(\operatorname{ArC}-\mathrm{H}), 103.2(\mathrm{ArC}-$ $\mathrm{H}), 51.7\left(\mathrm{CH}-\mathrm{CH}_{3}\right), 15.7\left(\mathrm{CH}-\mathrm{CH}_{3}\right)$. HRMS (ESI-) $\mathrm{m} / z[\mathrm{M}-\mathrm{H}]^{-}$ calcd. 402.0983 found 402.0982 .

\section{Synthesis of S21}

S20 (50 mg, $0.124 \mathrm{mmol})$, DCC $(25 \mathrm{mg}, 0.121 \mathrm{mmol})$ and $\mathrm{N}$-hydroxymaleimide $(14 \mathrm{mg}, 0.124 \mathrm{mmol}$ ) were dissolved in EtOAc/1,4-dioxane $(2: 1,2 \mathrm{~mL})$ and stirred at room temperature overnight. Then, the solvent was lyophilised on a Schlenk line, the crude solid was dissolved in EtOAc $(2.5 \mathrm{~mL})$ and cooled down to $4^{\circ} \mathrm{C}$ for $1 \mathrm{~h}$. The white precipitate of DCU was removed by centrifugation at $4^{\circ} \mathrm{C}$ and $21 \mathrm{kRCF}$ for $15 \mathrm{~min}$. The supernatant was dried to produce $\mathbf{S 2 1}$ as a bright yellow powder (58 mg, 95\%). The NMR spectra showed extra peaks which were attributed to atropoisomers and the presence of trace amounts of DCU. ${ }^{1} \mathbf{H}-$ NMR $\left(500 \mathrm{MHz}, \mathrm{DMSO}-d_{6}\right) \delta(\mathrm{ppm}): 9.99(1 \mathrm{H}, \mathrm{s}, \mathrm{OH}$ or $\mathrm{NH})$, $9.89(1 \mathrm{H}, \mathrm{s}, \mathrm{OH}$ or $\mathrm{NH}), 7.83(1 \mathrm{H}, \mathrm{m}, \mathrm{Ar}-H), 7.57(2 \mathrm{H}, \mathrm{m}, \mathrm{Ar}-H)$, $7.17\left(2 \mathrm{H}, \mathrm{s}^{\mathrm{br}}\right.$, maleimide Ar- $\left.H\right), 7.05(1 \mathrm{H}, \mathrm{m}, \mathrm{Ar}-H), 6.61(2 \mathrm{H}, \mathrm{m}$, Ar- $H), 6.55(1 \mathrm{H}, \mathrm{m}, \mathrm{Ar}-H), 6.49(2 \mathrm{H}, \mathrm{m}, \mathrm{Ar}-H), 6.38(1 \mathrm{H}, \mathrm{m}, \mathrm{dd}$ $\left.J_{1}=8.7 \mathrm{~Hz} J_{2}=2.4 \mathrm{~Hz}, \mathrm{Ar}-\mathrm{H}\right), 4.11\left(1 \mathrm{H}, \mathrm{q} J=7.1 \mathrm{~Hz}, \mathrm{CH}-\mathrm{CH}_{3}\right)$, $1.26\left(3 \mathrm{H}, \mathrm{d} J=7.1 \mathrm{~Hz}, \mathrm{CH}-\mathrm{CH}_{3}\right) 0.1^{3} \mathrm{C}-\mathrm{NMR}(160 \mathrm{MHz}, \mathrm{DMSO}-$ $\left.d_{6}\right) \delta(\mathrm{ppm}): 167.28(C=\mathrm{O}), 165.96(C=\mathrm{O}), 164.38(C=\mathrm{O}), 158.71$ $(C=\mathrm{O}), 157.36(\operatorname{ArC}), 153.20(\operatorname{ArC}), 152.13(\operatorname{ArC}), 133.43$ and 133.09 (maleimide $\mathrm{CH}=\mathrm{CH}), 131.91(\mathrm{ArC}-\mathrm{H}), 130.07(\mathrm{ArC}-\mathrm{H})$, $129.68(\mathrm{ArC}), 129.45(\mathrm{ArC}-\mathrm{H}), 128.78(\mathrm{ArC}-\mathrm{H}), 123.85(\mathrm{ArC}-$ $\mathrm{H}), 122.58(\mathrm{ArC}-\mathrm{H}), 112.37(\operatorname{ArC}-\mathrm{H}), 112.11(\mathrm{ArC}-\mathrm{H}), 108.47$ $(\mathrm{ArC}), 107.62(\mathrm{ArC}), 102.41(\mathrm{ArC}-\mathrm{H}), 102.06(\mathrm{ArC}-\mathrm{H}), 48.16$ $\left(\mathrm{CH}-\mathrm{CH}_{3}\right), 15.05\left(\mathrm{CH}-\mathrm{CH}_{3}\right)$. HRMS (ESI-) $\mathrm{m} / z[\mathrm{M}-\mathrm{H}]^{-}$calcd. 497.0985 found 497.0992 .

\section{Fluorescence Spectroscopy Study of the Stability of DNA-Conjugated Activated Esters}

The tetramethylrhodamine (TAMRA)/disulfide-labeled DNA hairpin $\mathbf{S 4}\left(1 \mu \mathrm{L}, 1 \mathrm{mM}\right.$ in $\left.\mathrm{H}_{2} \mathrm{O}, 1 \mathrm{nmol}\right)$ was thermally annealed with the complementary biotinylated strand $\mathbf{S 5}(1.1 \mu \mathrm{L}, 1.1 \mathrm{mM}$ in $\mathrm{H}_{2} \mathrm{O}, 1.1 \mathrm{nmol}$ ) in phosphate buffer solution (PBS, $10 \mu \mathrm{L}$, $0.1 \mathrm{M}, \mathrm{pH}$ 7.0). The disulfide group was reduced with tris(2carboxyethyl)phosphine hydrochloride (TCEP, $0.5 \mu \mathrm{L}, 0.5 \mathrm{M}$ in $\mathrm{H}_{2} \mathrm{O}$ ) at $18^{\circ} \mathrm{C}$ for $1.25 \mathrm{~h}$. Then, the resulting double stranded DNA (dsDNA) was conjugated to streptavidin-coated magnetic nanoparticles (Dynabeads, Thermofisher), and transferred into Gly $0.07(200 \mu \mathrm{L})$. The maleimide ester S21 $(1 \mathrm{mg}, 2.5 \mu \mathrm{mol})$ was added to the solution and allowed to react for $2 \mathrm{~h}$. The nanoparticle-supported DNA-conjugated activated ester was transferred into clean Gly 0.07 and the hairpin was released by toehold-mediated strand exchange by addition of one equivalent of strand $\mathbf{S 6}$ at $18^{\circ} \mathrm{C}$ for $2 \mathrm{~h}$ to produce an approximately $5 \mu \mathrm{M}$ solution of 4 . Finally, the solution of $4(5 \mu \mathrm{L})$ was diluted in the DES of interest $(95 \mu \mathrm{L})$, the resulting solution briefly centrifuged, and the fluorescein (FAM) fluorescence recorded over $24 \mathrm{~h}$ in a Mx3005P qPCR instrument (Agilent). The spectral overlap between FAM fluorophore (S21) and TAMRA-labeled DNA (S4) was also determined (Figure S4).

\section{DNA-Templated Synthesis of Peptide Bonds}

Disulfide-labeled DNA S7 $\left(10 \mu \mathrm{L}, 1 \mathrm{mM}\right.$ in $\left.\mathrm{H}_{2} \mathrm{O}, 10 \mathrm{nmol}\right)$ was mixed with TCEP solution $(2 \mu \mathrm{L}, \mathrm{pH} 4$ corrected with $5 \mathrm{M} \mathrm{NaOH}, 1 \mu \mathrm{mol})$ in a microcentrifuge tube. The solution was shaken at $18^{\circ} \mathrm{C}$ for $1.25 \mathrm{~h}$. Maleimide activated ester S21 $(108 \mu \mathrm{L}, 37 \mathrm{mM}$ in DMF, $4 \mu \mathrm{mol})$ was added and the combined solution shaken at $18^{\circ} \mathrm{C}$ for $1.0 \mathrm{~h}$ to produce the DNA-conjugated activated ester, 6 . The volume of the solution was reduced to approximately $50 \mu \mathrm{L}$ by freeze-drying. The previous solution was diluted with $\mathrm{Gly}_{0.07}(4,950 \mu \mathrm{L})$, and 
amine-labeled DNA $7\left(10 \mu \mathrm{L}, 1 \mathrm{mM}\right.$ in $\left.\mathrm{H}_{2} \mathrm{O}, 10 \mathrm{nmol}\right)$ added. The resulting mixture was vigorously shaken until the solution was homogeneous and then shaken at $18^{\circ} \mathrm{C}$ overnight. The DES solution was diluted with an excess of $\mathrm{H}_{2} \mathrm{O}$ and the DNA strands transferred into $\mathrm{H}_{2} \mathrm{O}$ for HPLC/LC-MS analysis by repeated centrifugal ultrafiltration using a $3 \mathrm{kDa}$ molecular weight cut-off (MWCO) Amicon spin filter. When the DNAtemplated reaction was performed in aqueous solution, the activated ester solution in DMF was diluted with PBS $(4,950 \mu \mathrm{L}$, $0.1 \mathrm{M}, \mathrm{pH}$ 7.5) containing the complementary amine-labeled DNA 7.

\section{Amine-Labeled DNA Reactivity in DES/Triethylamine $\left(\mathrm{Et}_{3} \mathrm{~N}\right)$}

Amine-labeled DNA $10\left(1 \mu \mathrm{L}, 1 \mathrm{mM}\right.$ in $\left.\mathrm{H}_{2} \mathrm{O}, 1 \mathrm{nmol}\right)$ was diluted in the appropriate solvent $(100 \mu \mathrm{L})$. $N$-hydroxysuccinimide ester $11(\sim 0.3 \mathrm{mg}, 1 \mu \mathrm{mol})$ was added, and the mixture shaken overnight at $20^{\circ} \mathrm{C}$. The product was transferred into $\mathrm{H}_{2} \mathrm{O}$ by dilution of the samples and successive centrifugal ultrafiltration using a $3 \mathrm{kDa}$ MWCO Amicon spin filter. The product was analyzed by HPLC and LC-MS.

\section{Storage of Activated Esters in Gly 0.07}

Disulfide-labeled DNA S11 ( $3 \mu \mathrm{L}, 1 \mathrm{mM}$ in $\left.\mathrm{H}_{2} \mathrm{O}, 3 \mathrm{nmol}\right)$ was mixed with TCEP solution $(3 \mu \mathrm{L}, \mathrm{pH} 4$ corrected with $5 \mathrm{M}$ $\mathrm{NaOH}, 1.5 \mu \mathrm{mol}$ ) in a microcentrifuge tube. The solution was shaken at $18^{\circ} \mathrm{C}$ for $1.25 \mathrm{~h}$. Maleimide activated ester S21 (54 $\mu \mathrm{L}$, $22 \mathrm{mM}$ in DMF, $1.2 \mu \mathrm{mol}$ ) was added and the combined solution was shaken at $18^{\circ} \mathrm{C}$ for $1.0 \mathrm{~h}$ to produce the DNA-conjugated activated ester 13. This sample was divided into 3 aliquots and used as follows. (1) Storage in Gly $y_{0.07}$ : the activated ester solution $(20 \mu \mathrm{L})$ was diluted with $\mathrm{Gly}_{0.07}(180 \mu \mathrm{L})$, and the resulting solution was shaken at $18^{\circ} \mathrm{C}$ for $2.0 \mathrm{~h}$. The solution was diluted with PBS (1.3 mL, 0.1 M, pH 7.5) containing complementary amine-labeled DNA $15\left(1 \mu \mathrm{L}, 1 \mathrm{mM}\right.$ in $\left.\mathrm{H}_{2} \mathrm{O}, 1 \mathrm{nmol}\right)$. The solution was shaken at $18^{\circ} \mathrm{C}$ for $5 \mathrm{~h}$. Finally, the solution was diluted with 1 vol. of $\mathrm{H}_{2} \mathrm{O}$, the precipitate was centrifuged, and the DNA products were transferred into $\mathrm{H}_{2} \mathrm{O}$ by successive steps of dilution of the supernatant with $\mathrm{H}_{2} \mathrm{O}$ and concentration by centrifugal ultrafiltration on a $3 \mathrm{kDa}$ MWCO Amicon spin filter. The product was analyzed by HPLC and LC-MS. (2) Storage in PBS: the activated ester solution $(20 \mu \mathrm{L})$ was diluted with PBS (180 $\mu \mathrm{L}, 0.1 \mathrm{M}, \mathrm{pH} 7.0)$, and the resulting solution was shaken at $18^{\circ} \mathrm{C}$ for $2.0 \mathrm{~h}$. Then, the sample was treated as in (1). (3) Fast reaction in PBS: the activated ester solution $(20 \mu \mathrm{L})$ was diluted with PBS $(1,480 \mu \mathrm{L}, 0.1 \mathrm{M}, \mathrm{pH}$ 7.5) containing complementary amine-labeled DNA $15(1 \mathrm{nmol})$. The solution was shaken at $18^{\circ} \mathrm{C}$ for $5.0 \mathrm{~h}$. The products were transferred into $\mathrm{H}_{2} \mathrm{O}$ for LC-MS analysis as described previously. (4) Offtemplate control: maleimide activated ester (S21) $(18 \mu \mathrm{L}, 22 \mathrm{mM}$ in DMF, $400 \mathrm{nmol})$ was diluted in PBS $(1,482 \mu \mathrm{L}, 0.1 \mathrm{M}$, $\mathrm{pH}$ 7.5) containing amine-labeled DNA $15(1 \mu \mathrm{L}, 1 \mathrm{mM}$ in $\mathrm{H}_{2} \mathrm{O}, 1 \mathrm{nmol}$ ). The solution was shaken at $18^{\circ} \mathrm{C}$ for $5.0 \mathrm{~h}$ and the product was transferred into $\mathrm{H}_{2} \mathrm{O}$ for LC-MS analysis as described above.

\section{RESULTS AND DISCUSSION}

\section{The Stability of Activated Esters in DES and Aqueous Buffer}

We used the $N$-hydroxysuccinimide ester of $L$-alanine (NHSAla) as a model activated peptide building block. This had similar solution stability to more prebiotically feasible activating groups while allowing us to use established techniques to prepare the required DNA-conjugated esters (He and Liu, 2011). A preliminary stability experiment was performed using a smallmolecule NHS-Ala, $\mathbf{1}$. We followed the hydrolysis of $\mathbf{1}$ in several glycholine/water mixtures and in aqueous PBS using proton nuclear magnetic resonance $\left({ }^{1} \mathrm{H}-\mathrm{NMR}\right)$ spectroscopy (Figure 1 and Figure S1). 1 was dissolved in the appropriate solvent mixture and then left for $24 \mathrm{~h}$ at $24^{\circ} \mathrm{C}$. Samples were extracted with immiscible deuterated solvent at set timepoints, and the relative proportions of activated ester and degradation products ( 2 and 3 ) were determined based on their distinctive methyl ${ }^{1} \mathrm{H}$ NMR signals. Both the proportion of water and the presence of basic additives were investigated for their effect on the rate of ester degradation.

As expected, rapid degradation of the ester in aqueous PBS was observed, with only $25 \%$ remaining after $24 \mathrm{~h}$. In stark contrast, degradation in Gly 0.07 was very slow, with $\sim 90 \%$ of the activated ester intact after $24 \mathrm{~h}$. Increasing the $\mathrm{H}_{2} \mathrm{O}$ content to $50 \mathrm{vol} \%$ accelerated solvolysis substantially. We attempted to deliberately accelerate the degradation in glycholine by use of a basic additive, triethylamine $\left(\mathrm{Et}_{3} \mathrm{~N}\right)$. The presence of $2 \mathrm{mM}$ $\mathrm{Et}_{3} \mathrm{~N}$ in $\mathrm{Gly}_{0.07}$ had the same destabilizing effect as increasing the water content to $50 \mathrm{vol} \%$, while $10 \mathrm{mM} \mathrm{Et}_{3} \mathrm{~N}$ led to a similar rate of degradation to that observed in PBS. The effect of basic additives was studied by diluting the DES in $\mathrm{H}_{2} \mathrm{O}$

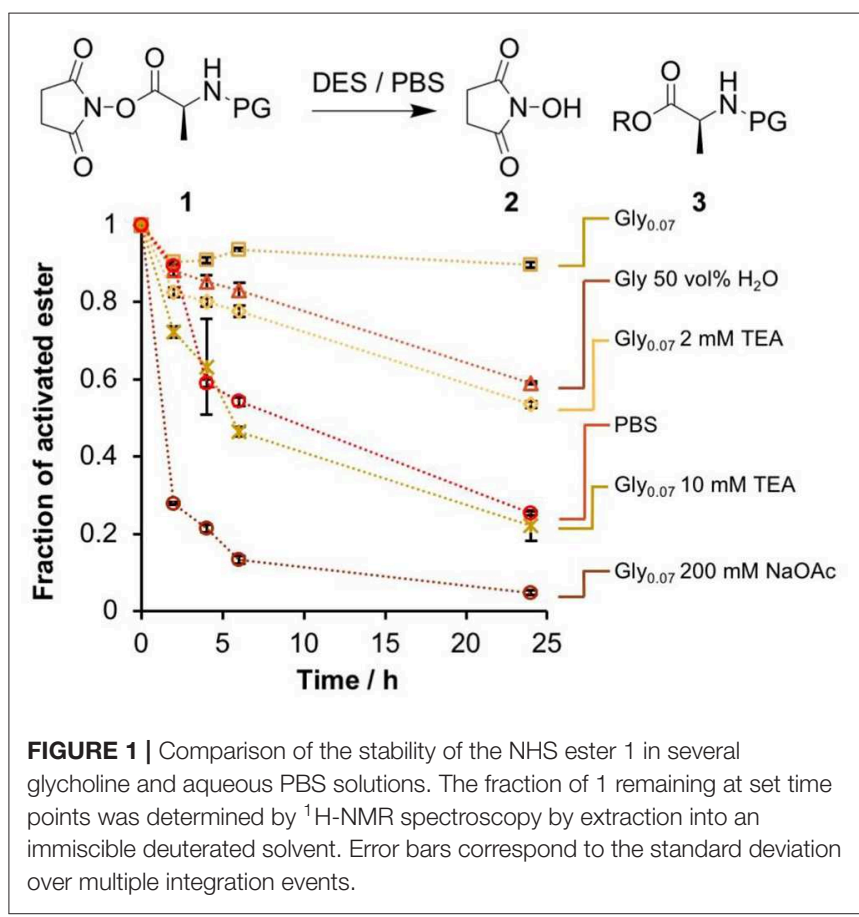


and measuring the $\mathrm{pH}$ of the resulting solution. $2 \mathrm{mM} \mathrm{Et}_{3} \mathrm{~N}$ produced a $\mathrm{pH}$ of 7.5 , while $10 \mathrm{mM} \mathrm{Et}_{3} \mathrm{~N}$ produced a $\mathrm{pH}$ of 9.9 (Table S2), it therefore seems likely that the observed differences in degradation rate arose as a result of the increased basicity of the solution.

The above ${ }^{1} \mathrm{H}$-NMR analysis could have been biased by differences in the extraction efficiency of $\mathbf{1}$ and 3 into the deuterated solvent used, so a complementary study that did not rely on this assumption was performed using reversedphase high performance liquid chromatography (RP-HPLC, Figure S2). The results were highly consistent with the ${ }^{1} \mathrm{H}$ NMR study, so we concluded that glycholine was indeed effective at stabilizing activated esters, and moved on to DNAbased experiments.

The thermal stability of double-stranded DNA (dsDNA) in glycholine $/ \mathrm{H}_{2} \mathrm{O}$ was assessed by fluorescence quenching and revealed that the duplex remained stable down to at least 7 vol\% $\mathrm{H}_{2} \mathrm{O}$ : in $\mathrm{Gly}_{0.07}$ the $T_{\mathrm{m}}$ of a 24 base pair dsDNA was $48^{\circ} \mathrm{C}$ (Figure S3). The addition of moderate volumes of $\mathrm{H}_{2} \mathrm{O}$ to DES has been used to reduce its viscosity and melting point (Ma et al., 2018; Smith et al., 2019), and resulted in increased conversion in enzymatic reactions (Durand et al., 2013; Guajardo et al., 2017). Furthermore, it has been shown that the microstructure of the DES is at least partially preserved upon the addition $\mathrm{H}_{2} \mathrm{O}$, up to $50 \mathrm{wt} \%$ (Hammond et al., 2017; Gabriele et al., 2019). Given this precedent, as well as the good stability of activated esters demonstrated above, $\mathrm{Gly}_{0.07}$ was used for experiments from this point onwards.

We were interested in assessing the stability of DNAconjugated activated esters in situ, avoiding the possibility of degradation occurring during analysis. To this end, a fluorescence quenching experiment was designed (Figure 2). A FAM-labeled NHS-Ala (S21) was synthesized from S17 through a multi-step procedure (Scheme $\mathbf{1}$ and Scheme S2, intermediates S18 to S20) and conjugated to a TAMRA-labeled DNA hairpin through thia-Michael addition. This design meant that in the ester form (4), FAM fluorescence would be quenched by the neighboring TAMRA group. Upon solvolysis of the ester to give 5, the FAM-labeled amino acid would diffuse away, triggering a measurable increase in fluorescence. We measured the fluorescence excitation and emission spectra of FAM and TAMRA in glycholine to ensure good spectral overlap was maintained in this solvent (Figure S4).

The DNA hairpin was supported on streptavidin-coated magnetic nanoparticles and transferred to Gly 0.07 for activated ester synthesis, ensuring minimal hydrolysis of the activated ester. Excess reagents were removed by magnetic purification, the hairpins were released into solution by toehold-mediated strand displacement and the nanoparticles removed with a magnet. The hairpin solution was diluted into an excess of the solvent of interest, and the evolution of the fluorescence over a $24 \mathrm{~h}$ period was recorded (Figure S5).

All experiments showed the expected increase in fluorescence due to solvolysis of the activated ester (Figure 2). While a rigorous quantitative kinetic analysis of the data was not possible due to uncertainties in the minimum and maximum fluorescence values, the results showed exactly the same trend as the small molecule experiments, with slow hydrolysis observed in Gly 0.07 . We therefore concluded that glycholine was also effective at stabilizing DNA-conjugated activated esters.
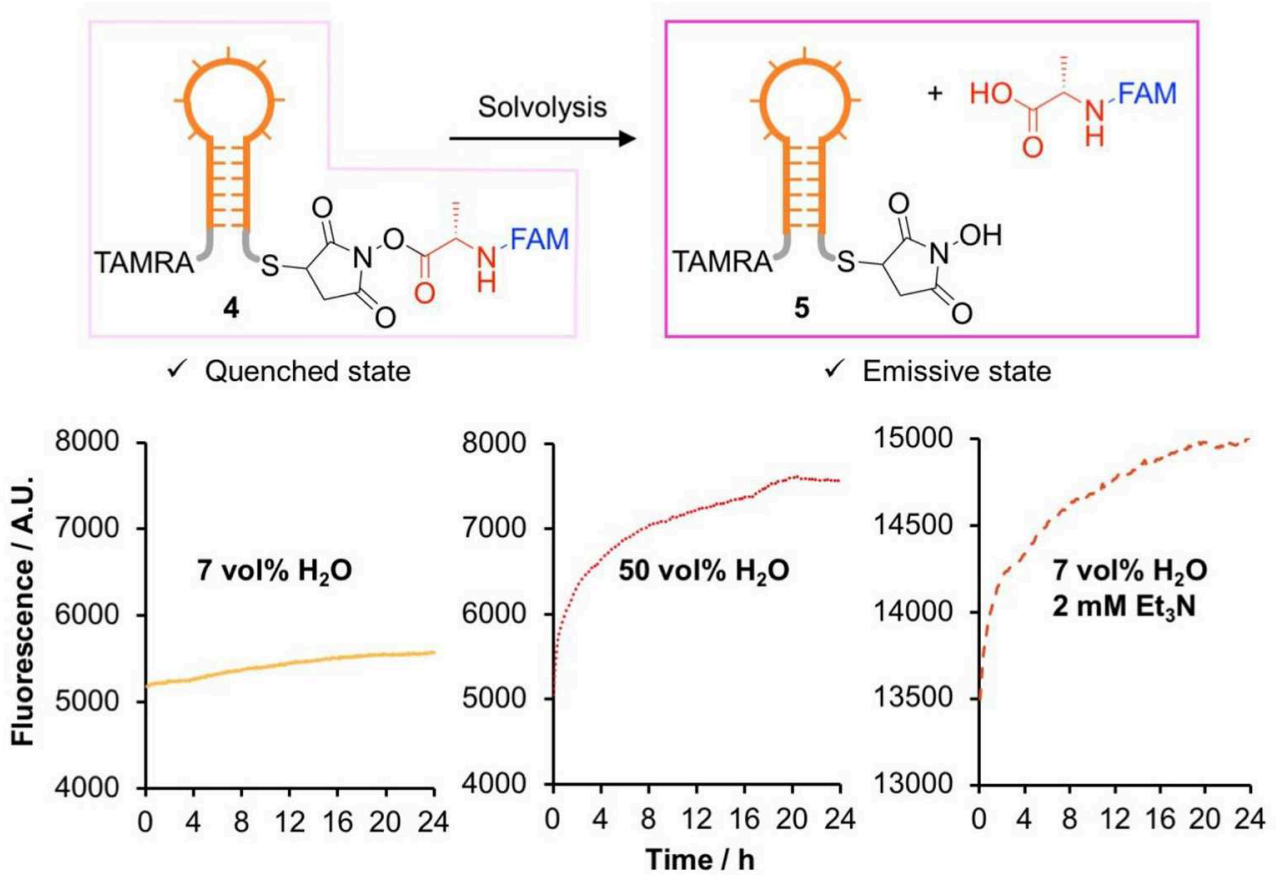

FIGURE 2 | Comparison of the stability of DNA-conjugated N-hydroxysuccinimide esters in several glycholine mixtures studied by fluorescence dequenching. 


\section{Nucleic Acid-Templated Synthesis of Peptide Bonds in DES}

Having demonstrated the higher stability of the activated esters in glycholine, we moved to a single-step NATS reaction using
NHS-Ala (Figure 3A). The DNA-conjugated activated ester $\mathbf{6}$ was prepared in $90 \mathrm{vol} \% \mathrm{DMF}$ and then transferred into a DES solution containing the complementary acceptor strand 7 . The DMF content was reduced to 1 vol\%, which did not substantially

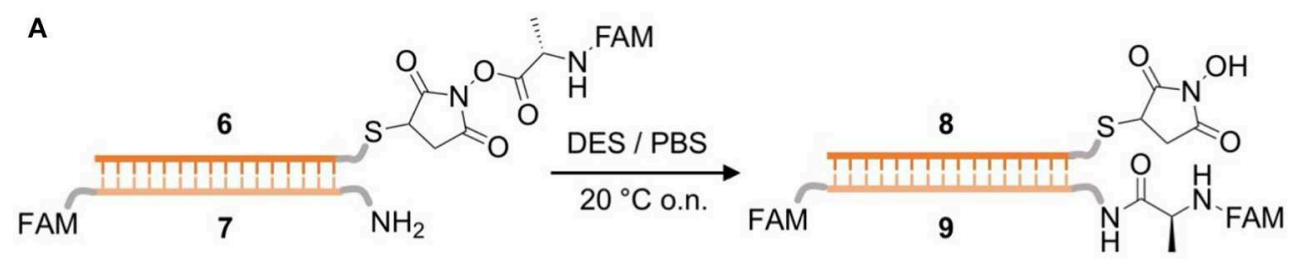

Deep Eutectic Solvent

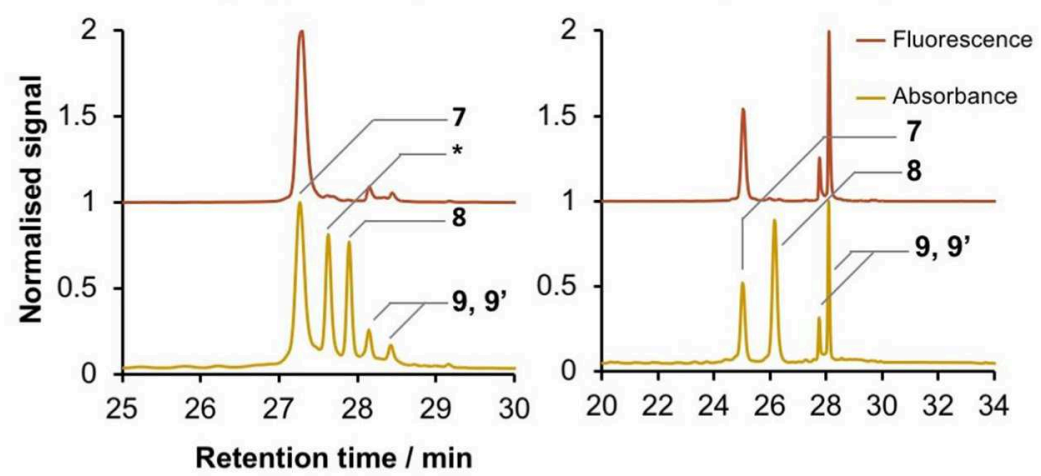

Buffered solution

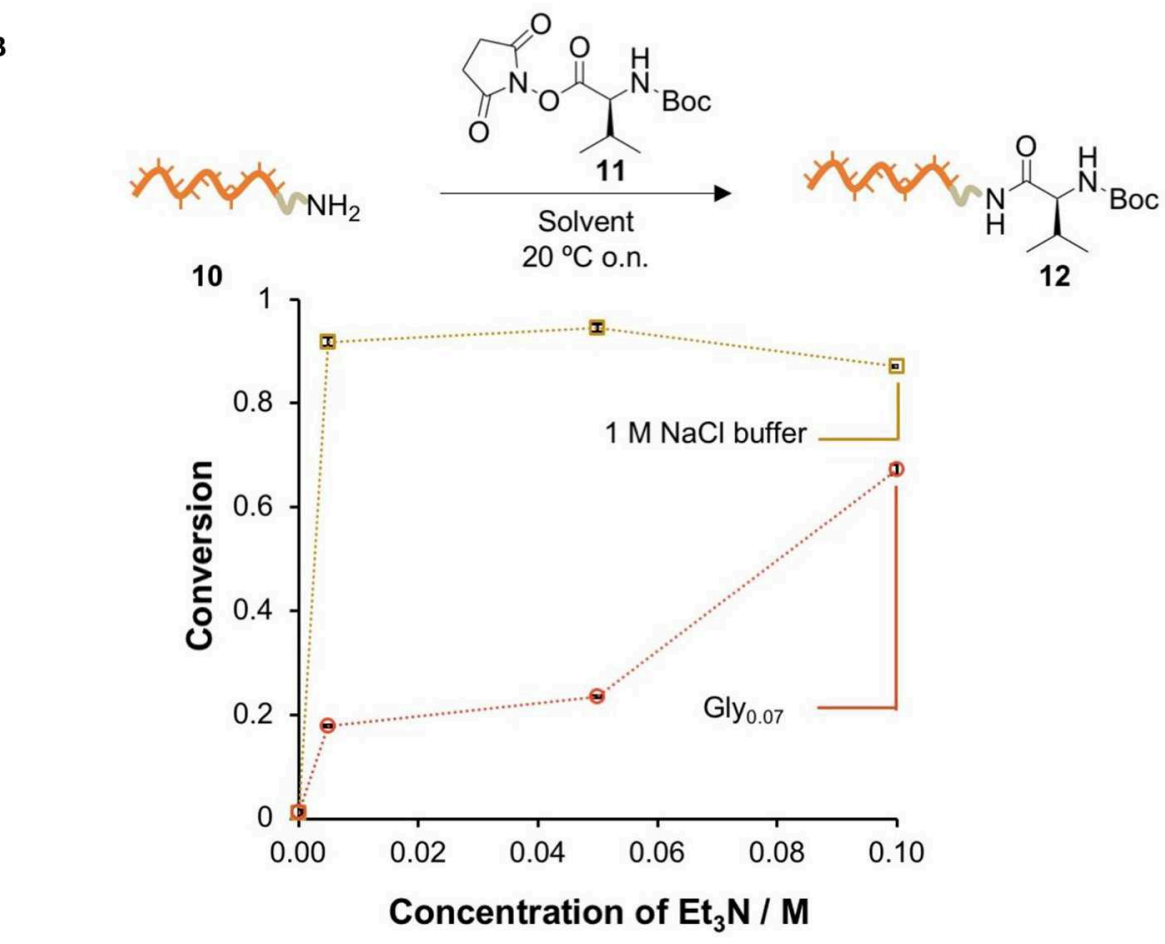

FIGURE 3 | DNA-templated formation of peptide bonds in DES. (A) Single-step DNA-templated synthesis of a peptide bond in glycholine and in PBS. The conversion was determined by HPLC integration of the signals corresponding to 7, 9, and 9' (isomers of the product). Peaks were identified by LC-MS (Bruker AmazonX): 7 $[\mathrm{M}-\mathrm{H}]^{-} \mathrm{m} / \mathrm{z}$ calcd. 9337.2 found 9336.0; 'DNA-SH [M-H] ${ }^{-} \mathrm{m} / \mathrm{z}$ calcd. 10615.2 found 10599.6; 8 [M-H] ${ }^{-} \mathrm{m} / \mathrm{z}$ calcd. 10712.0 found 10712.4; 9 and 9' (isomers) [M-H] ${ }^{-}$ $\mathrm{m} / \mathrm{z}$ calcd. 9723.6 (B) comparison of the reactivity of an amine-labeled DNA (10) in the presence of an excess of activated ester (11) in $\mathrm{Gly}_{0.07} / \mathrm{Et}_{3} \mathrm{~N}$ and $1 \mathrm{M} \mathrm{NaCl}$ $(\mathrm{aq}) / \mathrm{E} \mathrm{t}_{3} \mathrm{~N}$. The conversion was determined by HPLC integration of the signals corresponding to 10 and 12. Peaks were identified by LC-MS (Bruker AmazonX): 10 $[\mathrm{M}-\mathrm{H}]^{-} \mathrm{m} / \mathrm{z}$ calcd. 3897.7 found 3898.6; 11 [M-H] $]^{-} \mathrm{m} / \mathrm{z}$ calcd. 4096.8 found 4097.7 . Error bars correspond to the standard deviation over multiple integration events. 
A

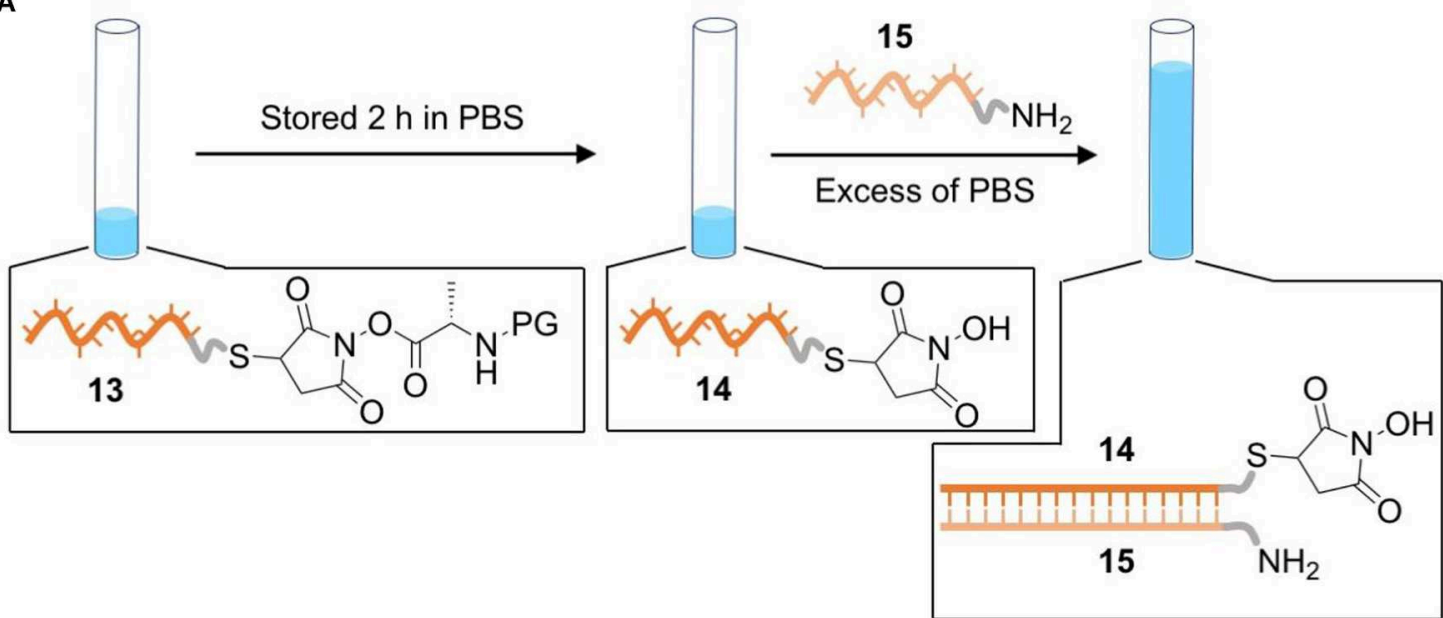

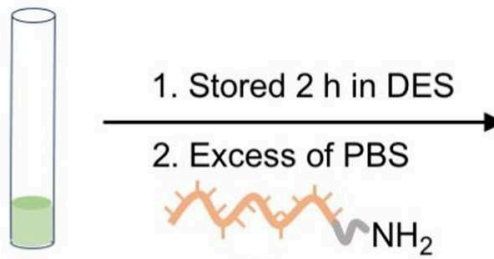

15

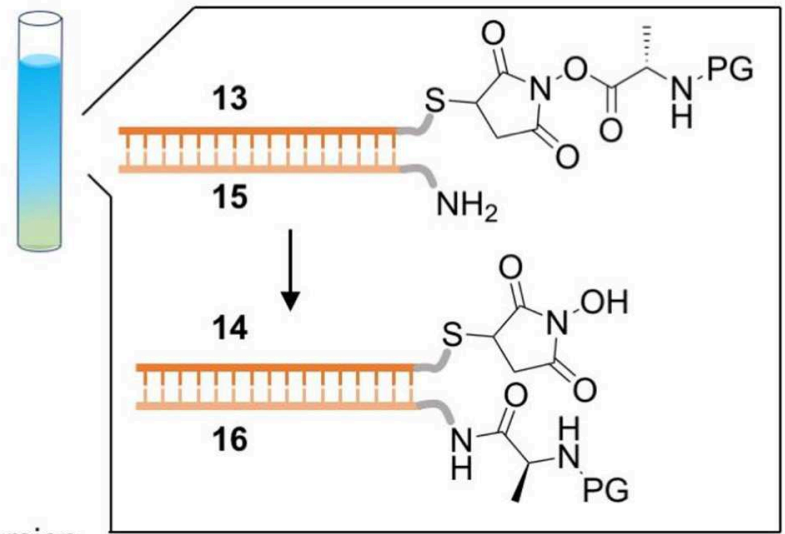

B

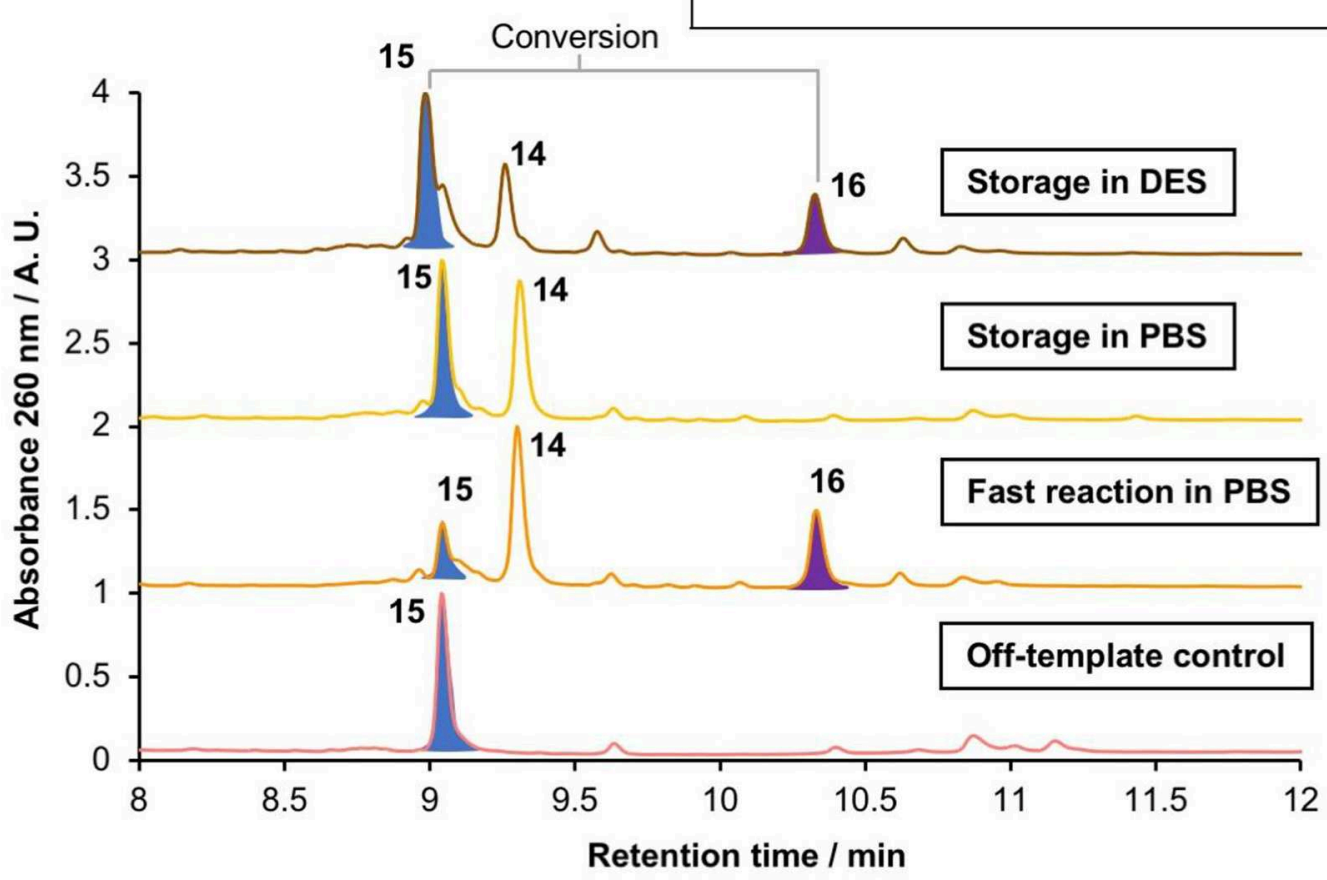

FIGURE 4 | Activating NATS "on demand." (A) Scheme of the storage of a DNA conjugated activated ester in PBS (0.1 M pH 7.0) or Glyo.07, followed by DNA-templated peptide bond formation in PBS. (B) LC-MS chromatograms of the products (Waters Xevo-G2-XS). 15 [M] ${ }^{0} \mathrm{~m} / z$ calcd. 10891.855 found 10891.522 ; $14[\mathrm{M}]^{0} \mathrm{~m} / \mathrm{z}$ calcd. 9558.632 found $9558.581 .16\left[\mathrm{M}^{0}{ }^{0} \mathrm{~m} / \mathrm{z}\right.$ calcd. 11201.935 found 11201.489. 
affect the duplex $T_{\mathrm{m}}$. Alternatively, 6 was synthesized in Gly ${ }_{0.07}$; this required longer reaction times $(2 \mathrm{~h})$ to reach the same yield attained in DMF, which we speculate was due to the higher viscosity of the DES. Controls mixing the acceptor strand with the small molecule reagents showed that no off-template reactions took place.

A control NATS reaction in PBS was also performed. While hydrolysis of the activated esters in aqueous solution was very fast, if the DNA conjugate 6 was isolated rapidly and transferred to a solution that contained the complementary amine-labeled DNA 7, the amide product 9 was formed in $48 \%$ conversion. By contrast, the formation of 9 in DES was only detected in very low yield (Figure 3A). A series of attempts to improve the conversion through the use of additives were not successful in raising the yield of 9 above $~ 5 \%$ (Table S3). We hypothesized that the low conversion in DES was due to a lack of reactivity of the amine moiety. To test this, amino-modified DNA 10 was reacted with a large excess of a small-molecule activated ester 11 in aqueous $1 \mathrm{M} \mathrm{NaCl}$ and glycholine solution that contained varying concentrations of $\mathrm{Et}_{3} \mathrm{~N}$ (Figure 3B). In aqueous solution, the conversion in the absence of base was very low, however the addition of a minimal amount of $\mathrm{Et}_{3} \mathrm{~N}$ resulted in nearly quantitative conversion. By contrast, in DES, very large amounts of $\mathrm{Et}_{3} \mathrm{~N}$ were required to achieve only moderate conversion (60\%). It is interesting to note that NATS of peptide bonds has previously been reported in $\mathrm{pH}$ 7.5 buffered solution, similar to the $\mathrm{pH}$ of the glycholine/ $\mathrm{Et}_{3} \mathrm{~N}$ solutions measured above, so $\mathrm{pH}$ cannot by itself explain the lack of amine reactivity in these solvent mixtures ( $\mathrm{He}$ and Liu, 2010).

These results highlighted that glycholine by itself could not have promoted prebiotic peptide synthesis. Stabilization of the activated ester comes at the cost of reduced amine reactivity, and increasing the reactivity of the amine can only be achieved by use of additives that destabilize the ester. However, recent hypotheses have proposed an important role for compartmentalisation in prebiotic processes (Mann, 2012). One could imagine a prebiotic system in which activated species are generated and stored in pockets of DES, and then transferred into aqueous solution to facilitate the formation of peptide products. We designed a transfer experiment to investigate this possibility (Figure 4A).

The DNA-conjugated activated ester $\mathbf{1 3}$ was stored in PBS or glycholine for $2 \mathrm{~h}$. The solution was then diluted with an excess of PBS containing the acceptor amino-DNA strand $\mathbf{1 5}$. The templated synthesis of the peptide product $\mathbf{1 6}$ was then quantified via HPLC by comparing peak areas (Figure 4B). The identity of the product was confirmed by LC-MS. A positive control was performed by removing the storage step and adding the acceptor strand (15) immediately after the synthesis of the activated ester 13. This resulted in $68 \%$ conversion to the peptide product. To check the importance of DNA templating, an off-template negative control was performed by adding the acceptor strand $\mathbf{1 5}$ to a solution of the small molecule activated ester S21 at the same concentration as the DNA strand $(670 \mathrm{nM})$. This showed no evidence of the formation of the peptide product 16, as expected. When the DNA-templated peptide synthesis was attempted following storage of the activated ester in PBS for $2 \mathrm{~h}$, no product was observed (Figure 4B). By contrast, DNA-templated synthesis following storage in glycholine resulted in $30 \%$ conversion to the peptide product.

\section{DISCUSSION}

Here, we demonstrate that glycholine-based DESs have a positive impact on the stability of DNA-conjugated activated esters when compared with buffered aqueous solutions. However, there is a marked reduction in the reactivity of amines, which prevents the NATS of peptides in these solvents. Our results highlight that it is very challenging to produce activated esters in aqueous media for subsequent templated reactions, as they quickly decompose; however, the synthesis of the activated ester in Gly0.07 provides a solution to this problem. By applying a two-stage process in which the activated ester was stored in DES and then transferred into PBS solution to trigger templated synthesis we achieved a moderate yield of $30 \%$. By comparison, no product was observed if the activated ester was stored in PBS.

It may be possible to circumvent the issue of amine deactivation we observe by the use of alternative DESs or other viscous solvents. For example, glycerol containing an appropriate concentration of $\mathrm{NaCl}$ has been shown to stabilize DNA duplexes (Bonner and Klibanov, 2000). Future work could investigate whether such solvent mixtures are more effective at promoting nucleic acid-templated peptide synthesis, and thus shine further light on whether increased activated ester stability is inevitably linked to decreased amine reactivity in these environments.

Finally, it is interesting to speculate how our results might be relevant to prebiotic translation. The high viscosity of DESs means that they mix only slowly with aqueous solutions, so this may have allowed a primitive form of compartmentalization in which the production and stabilization of activated species took place in a DES phase, followed by diffusion into the aqueous phase where templated chemistry could occur. Future experiments using simple DES/aqueous interfaces of this kind could provide fascinating insights into such prebiotic processes.

\section{DATA AVAILABILITY STATEMENT}

The datasets generated for this study are available on request to the corresponding author.

\section{AUTHOR CONTRIBUTIONS}

SN-P and TW designed the experiments, analyzed the data, and wrote and formatted the manuscript. SN-P carried out the experimental work.

\section{FUNDING}

This work was funded entirely by the European Research Council (grant ID 615142), which provided a studentship for SN-P and 
a postdoctoral fellowship for TW. Open access publication fees were funded by the University of Birmingham.

\section{ACKNOWLEDGMENTS}

The authors thank Prof. Rachel O'Reilly for her invaluable support during the performance of this work and Prof. Andrew Turberfield, Dr. Jonathan Bath, and Dr. Robert

\section{REFERENCES}

Abbott, A. P., Boothby, D., Capper, G., Davies, D. L., and Rasheed, R. K. (2004). Deep eutectic solvents formed between choline chloride and carboxylic acids: versatile alternatives to ionic liquids. J. Am. Chem. Soc. 126, 9142-9147. doi: $10.1021 /$ ja048266j

Abbott, A. P., Capper, G., Davies, D. L., Rasheed, R. K., and Tambyrajah, V. (2003). Novel solvent properties of choline chloride/urea mixtures. Chem. Commun. 2003, 70-71. doi: 10.1039/b210714g

Bonner, G., and Klibanov, A. M. (2000). Structural stability of DNA in nonaqueous solvents. Biotechnol. Bioeng. 68, 339-344. doi: 10.1002/(SICI)1097-0290(20000505)68:33.0.CO;2-O

Burcar, B., Pasek, M., Gull, M., Cafferty, B. J., Velasco, F., Hud, N. V., et al. (2016). Darwin's warm little pond: a one-pot reaction for prebiotic phosphorylation and the mobilization of phosphate from minerals in a urea-based solvent. Angew. Chem. Int. Ed. 55, 13249-13253. doi: 10.1002/anie.201606239

Crick, F. (1968). The origin of the genetic code. J. Mol. Biol. 38, 367-379. doi: 10.1016/0022-2836(68)90392-6

Crick, F. (1970). Central dogma of molecular biology. Nature 227, 561-563. doi: $10.1038 / 227561 \mathrm{a} 0$

Deck, C., Jauker, M., and Richert, C. (2011). Efficient enzyme-free copying of all four nucleobases templated by immobilized RNA. Nat. Chem. 3, 603-608. doi: 10.1038/nchem.1086

Durand, E., Lecomte, J., Baréa, B., Dubreucq, E., Lortie, R., and Villeneuve, P. (2013). Evaluation of deep eutectic solvent-water binary mixtures for lipase-catalyzed lipophilization of phenolic acids. Green Chem. 15, 2275-2282. doi: $10.1039 / \mathrm{c} 3 \mathrm{gc} 40899 \mathrm{j}$

Ekland, E. H., and Bartel, D. P. (1996). RNA-catalysed RNA polymerization using nucleoside triphosphates. Nature 382, 373-376. doi: 10.1038/382373a0

Gabriele, F., Chiarini, M., Germani, R., Tiecco, M., and Spreti, N. (2019). Effect of water addition on choline chloride/glycol deep eutectic solvents: characterization of their structural and physicochemical properties. J. Mol. Liq. 291:111301. doi: 10.1016/j.molliq.2019.111301

Gállego, I., Grover, M. A., and Hud, N. V. (2015). Folding and imaging of DNA nanostructures in anhydrous and hydrated deep-eutectic solvents. Angew. Chem. Int. Ed. 54, 6765-6769. doi: 10.1002/anie.201412354

Gao, J., Wang, P., and Giese, R. W. (2002). Xanthamide fluorescent dyes. Anal. Chem. 74, 6397-6401. doi: 10.1021/ac020368+

Gilbert, W. (1986). Origin of life: the RNA world. Nature 319:618. doi: $10.1038 / 319618 \mathrm{a} 0$

Guajardo, N., Domínguez de María, H. P., Ahumada, K., Schrebler, R. A., RamírezTagle, R., Crespo, F. A., et al. (2017). Water as cosolvent: nonviscous deep eutectic solvents for efficient lipase-catalyzed esterifications. Chem. Cat Chem. 9, 1393-1396. doi: 10.1002/cctc.201601575

Guerrier-Takada, C., Gardiner, K., Marsh, T., Pace, N., and Altman, S. (1983). The RNA moiety of ribonuclease $\mathrm{P}$ is the catalytic subunit of the enzyme. Cell 35, 849-857. doi: 10.1016/0092-8674(83)90117-4

Gull, M., Cafferty, B. J., Hud, N. V., and Pasek, M. A. (2017). Silicate-promoted phosphorylation of glycerol in non-aqueous solvents: a prebiotically plausible route to organophosphates. Life 7:29. doi: 10.3390/life7030029

Gull, M., Zhou, M., Fernández, F. M., and Pasek, M. A. (2014). Prebiotic phosphate ester syntheses in a deep eutectic solvent. J. Mol. Evol. 78, 109-117. doi: 10.1007/s00239-013-9605-9

Hammond, O. S., Bowron, D. T., and Edler, K. J. (2017). Effect of water upon deep eutectic solvent nanostructure: an unusual transition from
Oppenheimer for advice on the design of the DNA constructs and helpful discussions.

\section{SUPPLEMENTARY MATERIAL}

The Supplementary Material for this article can be found online at: https://www.frontiersin.org/articles/10.3389/fchem. 2020.00041/full\#supplementary-material

ionic mixture to aqueous solution. Angew. Chem. Int. Ed. 56, 9782-9785. doi: 10.1002/anie. 201702486

Hänle, E., and Richert, C. (2018). Enzyme-free replication with two or four bases. Angew. Chem. Int. Ed. 57, 8911-8915. doi: 10.1002/anie.2018 03074

He, C., Gállego, I., Laughlin, B., Grover, M. A., and Hud, N. V. (2017). A viscous solvent enables information transfer from gene-length nucleic acids in a model prebiotic replication cycle. Nat. Chem. 9, 318-324. doi: 10.1038/ nchem. 2628

He, C., Lozoya-Colinas, A., Gállego, I., Grover, M. A., and Hud, N. V. (2019). Solvent viscosity facilitates replication and ribozyme catalysis from an RNA duplex in a model prebiotic process. Nucleic Acids Res. 47, 6569-6577. doi: 10.1093/nar/gkz496

He, Y., and Liu, D. R. (2010). Autonomous multistep organic synthesis in a single isothermal solution mediated by a DNA walker. Nat. Nanotechnol. 5, 778-782. doi: 10.1038/nnano.2010.190

He, Y., and Liu, D. R. (2011). A sequential strand-displacement strategy enables efficient six-step DNA-templated synthesis. J. Am. Chem. Soc. 133, 9972-9975. doi: $10.1021 /$ ja201361t

Johnston, W. K., Unrau, P. J., Lawrence, M. S., Glasner, M. E., and Bartel, D. P. (2001). RNA-catalyzed RNA polymerization: accurate and general RNA-templated primer extension. Science 292, 1319-1325. doi: 10.1126/science.1060786

Kaiser, R. I., Maity, S., and Jones, B. M. (2015). Synthesis of prebiotic glycerol in interstellar ices. Angew. Chem. Int. Ed. 54, 195-200. doi: 10.1002/anie.201408729

Kanavarioti, A., Bernasconi, C. F., Doodokyan, D. L., and Alberas, D. J. (1989). Magnesium ion catalyzed phosphorus-nitrogen bond hydrolysis in imidazolide-activated nucleotides. relevance to template-directed synthesis of polynucleotides. J. Am. Chem. Soc. 111, 7247-7257. doi: 10.1021/ja00200a053

Kruger, K., Grabowski, P. J., Zaug, A. J., Sands, J., Gottschling, D. E., and Cech, T. R. (1982). Self-splicing RNA: autoexcision and autocyclization of the ribosomal RNA intervening sequence of tetrahymena. Cell 31, 147-157. doi: 10.1016/0092-8674(82)90414-7

Lannan, F. M., Mamajanov, I., and Hud, N. V. (2012). Human telomere sequence DNA in water-free and high-viscosity solvents: G-quadruplex folding governed by kramers rate theory. J. Am. Chem. Soc. 134, 15324-15330. doi: $10.1021 /$ ja303499m

Li, L., Prywes, N., Tam, C. P., Oflaherty, D. K., Lelyveld, V. S., Izgu, E. C., et al. (2017). Enhanced nonenzymatic RNA copying with 2aminoimidazole activated nucleotides. J. Am. Chem. Soc. 139, 1810-1813. doi: 10.1021/jacs.6b13148

Li, X., and Liu, D. R. (2004). DNA-templated organic synthesis: nature's strategy for controlling chemical reactivity applied to synthetic molecules. Angew. Chem. Int. Ed. 43, 4848-4870. doi: 10.1002/anie.200400656

Liu, Z., Mariani, A., Wu, L., Ritson, D., Folli, A., Murphy, D., et al. (2018). Tuning the reactivity of nitriles using $\mathrm{Cu}$ (ii) catalysis-potentially prebiotic activation of nucleotides. Chem. Sci. 9, 7053-7057. doi: 10.1039/C8SC02513D

Ma, C., Laaksonen, A., Liu, C., Lu, X., and Ji, X. (2018). The peculiar effect of water on ionic liquids and deep eutectic solvents. Chem. Soc. Rev. 47, 8685-8720. doi: 10.1039/C8CS00325D

Mamajanov, I., Engelhart, A. E., Bean, H. D., and Hud, N. V. (2010). DNA and RNA in anhydrous media: duplex, triplex, and G-quadruplex secondary structures in a deep eutectic solvent. Angew. Chem. Int. Ed. 49, 6310-6314. doi: 10.1002/anie.201001561 
Mann, S. (2012). Systems of creation: the emergence of life from nonliving matter. Acc. Chem. Res. 45, 2131-2141. doi: 10.1021/ar200281t

Mariani, A., Russell, D. A., Javelle, T., and Sutherland, J. D. (2018). A lightreleasable potentially prebiotic nucleotide activating agent. J. Am. Chem. Soc. 140, 8657-8661. doi: 10.1021/jacs.8b05189

Maugeri, Z., Leitner, W., and Domínguez De María, P. (2013). Chymotrypsincatalyzed peptide synthesis in deep eutectic solvents. Eur. J. Org. Chem. 2013, 4223-4228. doi: 10.1002/ejoc.201300448

Meng, W., Muscat, R. A., McKee, M. L., Milnes, P. J., El-Sagheer, A. H., Bath, J., et al. (2016). An autonomous molecular assembler for programmable chemical synthesis. Nat. Chem. 8, 542-548. doi: 10.1038/nchem.2495

Mondal, D., Sharma, M., Mukesh, C., Gupta, V., and Prasad, K. (2013). Improved solubility of DNA in recyclable and reusable bio-based deep eutectic solvents with long-term structural and chemical stability. Chem. Commun. 49, 9606-9608. doi: 10.1039/c3cc45849k

Okamura, H., Crisp, A., Hübner, S., Becker, S., Rovo, P., and Carell, T. (2019). Proto-urea-RNA (Wöhler RNA) containing unusually stable urea nucleosides. Angew. Chem. Int. Ed. 58, 18691-18696. doi: 10.1002/anie.2019 11746

O'Reilly, R. K., Turberfield, A. J., and Wilks, T. R. (2017). The evolution of DNAtemplated synthesis as a tool for materials discovery. Acc. Chem. Res. 50, 2496-2509. doi: 10.1021/acs.accounts.7b00280

Orgel, L. E. (1968). Evolution of the genetic apparatus. J. Mol. Biol. 38, 381-393. doi: 10.1016/0022-2836(68)90393-8

Pätzold, M., Siebenhaller, S., Kara, S., Liese, A., Syldatk, C., and Holtmann, D. (2019). Deep eutectic solvents as efficient solvents in biocatalysis. Trends Biotechnol. 37, 943-959. doi: 10.1016/j.tibtech.2019.03.007

Paul, N., and Joyce, G. F. (2002). A self-replicating ligase ribozyme. Proc. Natl. Acad. Sci. U.S.A. 99, 12733-12740. doi: 10.1073/pnas.2024 71099

Smith, E. L., Abbott, A. P., and Ryder, K. S. (2014). Deep eutectic solvents (DESs) and their applications. Chem. Rev. 114, 11060-11082. doi: 10.1021/cr30 0162p

Smith, P. J., Arroyo, C. B., Lopez Hernandez, F., and Goeltz, J. C. (2019). Ternary deep eutectic solvent behavior of water and urea choline chloride mixtures. J. Phys. Chem. B 123, 5302-5306. doi: 10.1021/acs.jpcb.8b12322

Steitz, T. A. (2008). A structural understanding of the dynamic ribosome machine. Nat. Rev. Mol. Cell Biol. 9, 242-253. doi: 10.1038/nrm2352

Szostak, J. W. (2012). The eightfold path to non-enzymatic RNA replication. J. Syst. Chem. 3:2. doi: 10.1186/1759-2208-3-2

Tamura, K., and Schimmel, P. (2001). Oligonucleotide-directed peptide synthesis in a ribosome- and ribozyme-free system. Proc. Natl. Acad. Sci. U.S.A. 98, 1393-1397. doi: 10.1073/pnas.98.4.1393
Tamura, K., and Schimmel, P. (2004). Chiral-selective aminoacylation of an RNA minihelix. Science 305:1253. doi: 10.1126/science.1099141

Turk, R. M., Chumachenko, N. V., and Yarus, M. (2010). Multiple translational products from a five-nucleotide ribozyme. Proc. Natl. Acad. Sci. U.S.A. 107, 4585-4589. doi: 10.1073/pnas.0912895107

Wagle, D. V., Zhao, H., and Baker, G. A. (2014). Deep eutectic solvents: sustainable media for nanoscale and functional materials. Acc. Chem. Res. 47, 2299-2308. doi: 10.1021/ar5000488

Xu, P., Zheng, G.-W., Zong, M.-H., Li, N., and Lou, W.-Y. (2017). Recent progress on deep eutectic solvents in biocatalysis. Bioresour. Bioprocess. 4, 34-52. doi: 10.1186/s40643-017-0165-5

Yarus, M. (2001). On translation by RNAs alone. Cold Spring Harb. Symp. Quant. Biol. 66, 207-216. doi: 10.1101/sqb.2001.66.207

Yonath, A. (2009). Large facilities and the evolving ribosome, the cellular machine for genetic-code translation. J. R. Soc. Interface 6, S575-S585. doi: 10.1098/rsif.2009.0167.focus

Zadeh, J. N., Steenberg, C. D., Bois, J. S., Wolfe, B. R., Pierce, M. B., Khan, A. R., et al. (2009). NUPACK: analysis and design of nucleic acid systems. J. Comput. Chem. 32, 170-173. doi: 10.1002/jcc.21596

Zhang, B., and Cech, T. R. (1997). Peptide bond formation by in vitro selected ribozymes. Nature 390, 96-100. doi: 10.1038/36375

Zhang, Q., De Oliveira Vigier, K., Royer, S., and Jérôme, F. (2012). Deep eutectic solvents: syntheses, properties and applications. Chem. Soc. Rev. 41, 7108-7146. doi: $10.1039 / \mathrm{c} 2 \mathrm{cs} 35178 \mathrm{a}$

Zhang, W., Pal, A., Ricardo, A., and Szostak, J. W. (2019). Templatedirected nonenzymatic primer extension using 2-methylimidazole-activated morpholino derivatives of guanosine and cytidine. J. Am. Chem. Soc. 141, 12159-12166. doi: 10.1021/jacs.9b06453

Zhao, C., Ren, J., and Qu, X. (2013). G-quadruplexes form ultrastable parallel structures in deep eutectic solvent. Langmuir 29, 1183-1191. doi: $10.1021 / \mathrm{la} 3043186$

Conflict of Interest: The authors declare that the research was conducted in the absence of any commercial or financial relationships that could be construed as a potential conflict of interest.

Copyright (C) 2020 Núñez-Pertiñez and Wilks. This is an open-access article distributed under the terms of the Creative Commons Attribution License (CC BY). The use, distribution or reproduction in other forums is permitted, provided the original author(s) and the copyright owner(s) are credited and that the original publication in this journal is cited, in accordance with accepted academic practice. No use, distribution or reproduction is permitted which does not comply with these terms. 